\title{
Association between Red Cell Distribution Width and Left Atrial Thrombus in Patients with Valvular Atrial Fibrillation
}

\author{
Mirza Alfiansyah*, Niniek Purwaningtyas
}

Department of Cardiology and Vascular Medicine, Faculty of Medicine, University of Sebelas Maret, Surakarta, Central Java, Indonesia

\author{
ARTICLE INFO \\ *Corresponding author \\ Email: \\ mirza.alfiansyah@gmail.com \\ Address: \\ Jalan Ir. Sutami No. 36A, Kentingan, Surakarta, \\ 57126, Indonesia \\ Keywords: \\ red cell distribution width; left atrial thrombus; \\ valvular atrial fibrillation \\ Manuscript submitted: December 19, 2019 \\ Revised and accepted: May 17, 2020
}

\begin{abstract}
Background: Red cell distribution width (RDW) is a quantitative measure of variability in the size of circulating erythrocytes and previously shown to provide information concerning the prothrombotic status or adverse outcome of cardiovascular disease. Left atrial thrombus (LAT) is commonly detected in patients with valvular atrial fibrillation (VAF) due to rheumatic mitral valve stenosis (RMVS) but there is very limited data regarding the predictive value of RDW for the development of LAT in these patients.
\end{abstract}

Aim: To determine the association between RDW and LAT in VAF patients.

Methods: A total of 58 patients were included in a retrospective observational study between January 2016 to December 2016 in patients who admitted to Dr. Moewardi General Hospital, due to symptomatic VAF. Blood examination and transthoracic echocardiography were performed to all patients. LAT was defined as a fixed or mobile echogenic mass within left atrium (LA) and left atrial appendage (LAA). The RDW was compared between a patient with LAT or without LAT.

Results: There were 28 patients (mean age: $46.2 \pm 13.3$ years) in LAT( + ) group and 30 patients (mean age: $45.6 \pm 11.5$ years) in LAT(-) group. RDW was significantly higher in LAT( + ) group $(14.4 \pm 1.8 \%$ vs. $13.3 \pm 1.5 \%, p=0.010)$. The RDW was independent predictor of LAT by multivariate analysis (OR 1.619; $\mathrm{p}=0.020 ; 95 \% \mathrm{CI}: 1.079-2.429$ ). The cut-off RDW value for LAT was $>13.5 \%$ with a sensitivity of $73.3 \%$ and a specificity of $64.3 \%$ (area under curve $=0.700 ; 95 \%$ CI: $0.562-0.838 ; p=0.009$ ). The prevalence of LAT was significantly higher in patient with an RDW $>13.5 \%$ than in those with an RDW $<13.5 \%$ (64.3\% and $35.7 \%, p=0.002)$, with prevalence ratio 5.91 .

Conclusion: This study shows that a higher level of RDW has an association with the presence of LAT and an independent risk factor of LAT formation in patients with VAF.

\section{INTISARI}

Latar Belakang: Red cell distribution width (RDW) merupakan ukuran kuantitatif variabilitas eritrosit yang bersirkulasi dan disebutkan sebelumnya dapat memberikan informasi mengenai status protrombotik atau komplikasi yang buruk dari penyakit kardiovaskular. Trombus atrium kiri (TAK) umumnya terdeteksi pada pasien dengan fibrilasi atrium katup (FAK) karena stenosis katup mitral rematik. Namun data yang ada mengenai nilai prediktif RDW pada terbentuknya TAK pada pasien FAK masih sangat terbatas

Tujuan: Untuk mengetahui adanya hubungan antara RDW dengan TAK pada pasien FAK.

Metode: Sebanyak 58 pasien dilibatkan dalam penelitian observasional retrospektif antara Januari 2016 hingga Desember 2016 pada pasien yang dirawat di Rumah Sakit Umum Dr. Moewardi karena FAK. Pemeriksaan 
darah dan ekokardiografi transtorakal dilakukan untuk semua pasien. TAK didefinisikan sebagai massa ekogenik yang tetap atau bergerak di atrium kiri dan apendik atrium kiri. RDW dibandingkan antara pasien dengan TAK atau tanpa TAK.

Hasil: Ada 28 pasien (usia rata-rata $46,2 \pm 13,3$ ) pada kelompok TAK (+) dan 30 pasien (usia rata-rata $45,6 \pm 11,5$ ) pada kelompok TAK $(-)$. RDW secara signifikan lebih tinggi pada kelompok TAK (+) $(14,4 \pm 1,8 \%$ vs $13,3 \pm 1,5 \%$, p $=0,010)$. RDW adalah prediktor independen TAK pada analisis multivariat dengan (OR 1,619; $p=0,020 ; 95 \%$ CI 1,079-2,429). Nilai RDW titik potong untuk TAK adalah $>13,5 \%$ dengan sensitivitas 73,3\% dan spesifisitas $64,3 \%$ $($ AUC $=0,700 ; 95 \%$ CI 0,562-0,838; $\mathrm{p}=0,009)$. Prevalensi TAK secara signifikan lebih tinggi pada pasien dengan RDW $>13,5 \%$ dibandingkan dengan RDW $<13,5 \%(64,3 \%$ dan $35,7 \%, \mathrm{p}=0,002)$ dengan rasio prevalesi 5.91.

Kesimpulan: Studi ini menunjukkan bahwa nilai RDW yang lebih tinggi memiliki hubungan dengan adanya TAK dan faktor risiko independen terbentuknya TAK pada pasien dengan FAK.

\section{Introduction}

The prevalence of valvular atrial fibrillation (VAF) due to rheumatic mitral valve stenosis (RMVS) in developing countries is quite high and it can be predisposition risk of stroke. ${ }^{1}$ This is due to the slowing of blood flow and stasis in the left atrium (LA) due to RMVS causing thrombus formation and the thrombus formed can circulate systemically from the LA and can cause embolic complications, especially stroke. ${ }^{2}$ This incidence of embolism increases with the presence of atrial fibrillation (AF) which coincides with mitral valve stenosis. ${ }^{3}$ However, this cannot explain the formation of thrombus in the LA in RMVS patients only because of valve obstruction. ${ }^{2}$

Red cell distribution width (RDW) is a quantitative measure of variability in the size of circulating erythrocytes and has been previously shown to provide information concerning the prothrombotic status or poor complications of cardiovascular disease. ${ }^{4}$ Previous studies have shown an association of RDW with the formation of left atrial thrombus (LAT) or spontaneous echo contrast (SEC) in patients with non-valvular atrial fibrillation and mitral valve stenosis. ${ }^{2,5}$

However, the existing data regarding the predictive value of RDW in the formation of LAT in VAF patients is still very limited, so this study aims to determine the relationship between RDW and LAT seen with transthoracic echocardiography (TTE) in VAF patients.

\section{Methods}

This was a retrospective observational study. The subject was VAF patients due to RMVS who underwent treatment at Dr. Moewardi General Hospital, Indonesia from January 2016-December 2016. Patient data were obtained from medical records containing information about demographics, comorbidities, electrocardiography (ECG), laboratory examination and echocardiography reports.

The inclusion criteria in this study were all patients VAF due to severe RMVS with mitral valve area (MVA) $<1 \mathrm{~cm} 2$ confirmed by TTE. 6 The AF diagnosis was obtained from 12-lead ECG records. Exclusion criteria: anemia was defined according to the World Health Organization (WHO) as hemoglobin levels of $<12 \mathrm{~g} / \mathrm{dL}$ in women or $<13$ $\mathrm{g} / \mathrm{dL}$ in men, patients with systemic infection or inflammation, abnormal liver function was defined as elevation of transaminases levels to $>3$ times the upper limit of normal, chronic kidney disease was defined as estimated glomerular filtration rate (eGFR) $<60 \mathrm{~mL} / \mathrm{min} /$ $1.73 \mathrm{~m} 2$, patients who were not examined for RDW, hematological disorders and patients with a history of transfusion or bleeding while being treated.

Hypertension (HT) was defined as a systolic blood pressure of $\geq 140 \mathrm{mmHg}$ and/ or diastolic blood pressure of $\geq 90 \mathrm{mmHg}$ or medication use. ${ }^{2,7}$ Diabetes mellitus (DM) was defined as fasting blood glucose levels of $\geq 126 \mathrm{mg} / \mathrm{dl}$ or the use of insulin or oral hypoglycemic medication. ${ }^{2,8}$ Stroke was defined as a neurologic deficit lasting $24 \mathrm{~h}$ (TIA) or longer (stroke) and caused by ischemia. ${ }^{3}$

Patients were divided into two groups. The LAT $(+)$ group consisted of patients with VAF and there is thrombus in the LA or LAA while the LAT(-) group consisted of patients with VAF and without thrombus in the LA or LAA.

Blood test data was obtained from the patient's medical record. Complete blood tests and standard biochemical examinations were obtained from patient day one on hospital admission and were carried out using an automatic blood examination machine (Mindray BC-5800 and TMS 24i premium) in hospital clinical pathology laboratory. Hemoglobin, hematocrit, leukocytes, platelets, neutrophils, lymphocytes and RDW were recorded. Also, biochemical examinations include blood glucose, creatinine, urea, alanine aminotransferase (ALT), aspartate aminotransferase (AST) and blood clotting functions: international normalized ratio (INR) was also recorded. A neutrophil-lympocyte ratio (NLR) was calculated from the results of the comparison between neutrophils and lymphocytes. 
The echocardiographic data was obtained from echocardiographic reports. Echocardiography examination was obtained from patient day three on hospital admission uses TTE. The echocardiography machine was used by Vivid S6 Cardiovascular (General Electric). The echocardiographic examination included left ventricular (LV) diameter and left ventricular ejection fraction (LVEF) were assessed by the Teicholtz method, LA diameter and tricuspid annular plane systolic excursion (TAPSE) were assessed by M-mode, and MVA with a planimetric method and the presence of LAT. LAT was defined as homogeneous mobile or fixed mass with similar echo density to the myocardium located at the LA and LAA. ${ }^{2}$

Statistical analysis was performed using Statistical Package for the Social Sciences (SPSS) 19 (IBM, Chicago, USA) and Microsoft Excel 2013 (Microsoft, Washington, USA). Categorical variables were displayed as frequencies and percentages. Continuous variables with normal data distribution were shown as mean \pm standard deviation (SD), while variables without normal distribution were shown as median (minimum-maximum). Analysis of normality was performed using the Kolmogorov-Smirnov test. A chi-square test was used to compare categorical variables. The independent t-test was used to compare continuous variables with normal distribution and the Mann-Whitney U test was used to compare continuous variables with non-normal distribution. To identify independent predictors of LAT formation, multivariate logistic regression analysis was performed by entering parameters that had a value of $p<0.25$. The receiver operating characteristic (ROC) curve analysis was used to determine the cut-off value, sensitivity, and specificity of RDW. A value of $\mathrm{p}<0.05$ was considered significant within a $95 \%$ confidence interval (CI).

\section{Result}

There were 100 patients with AF due to RMVS, but 42 patients were excluded from the study because they met exclusion criteria (Figure 1). Thus only 58 patients were included in this study. Then 58 patients were divided into two groups, patients LAT $(+)(n=28)$ and LAT $(-)(n=30)$.

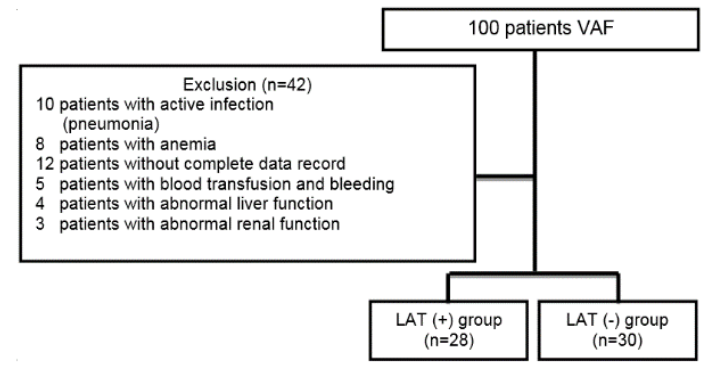

Figure 1. Flow chart of this study

The baseline characteristics of patients are presented in table 1 . The mean age of patients was $46.2 \pm 13.3$ years in the LAT( + ) group and $45.6 \pm 11.5$ years in the LAT(-) group. There were no differences in age, sex, and comorbidities
(HT, DM, and stroke). In the analysis of laboratory results, there were no differences in blood glucose, urea, creatinine, AST, ALT, hemoglobin, hematocrit, leukocytes, platelets, neutrophils, lymphocytes, NLR and INR values. In LAT(+) group, the RDW values were higher than LAT(-) group, namely $14.4 \pm 1.8 \%$ vs. $13.3 \pm 1.5 \%$, $p<0.05$. On the results of echocardiographic parameter analysis, there were no significant differences between the two groups.

Table 1.

Baseline characterictic based on LAT

\begin{tabular}{|c|c|c|c|}
\hline Variable & $\begin{array}{l}\text { LAT }(+) \\
(n=28)\end{array}$ & $\begin{array}{l}\text { LAT(-) } \\
(n=30)\end{array}$ & $\mathrm{p}$ \\
\hline Age(year) & $46.2 \pm 13.3$ & $45.6 \pm 11.5$ & 0.842 \\
\hline Sex & & & 0.571 \\
\hline Male,n (\%) & $11(39.3)$ & $14(46.7)$ & \\
\hline Female, n (\%) & 17 (60.7) & $16(53.3)$ & \\
\hline Hypertension, n (\%) & $3(10.7)$ & $1(6.6)$ & 0.268 \\
\hline Diabetes melitus, n (\%) & $3(10.7)$ & $3(10.0)$ & 0.929 \\
\hline Stroke,n (\%) & 5 (17.9) & $1(3.3)$ & 0.070 \\
\hline LA diameter (mm) & $52.0(44-59)$ & $49.5(42-58)$ & 0.145 \\
\hline Mitral valve area $\left(\mathrm{cm}^{2}\right)$ & $0.7(0.4-0.9)$ & $0.8(0.4-1)$ & 0.362 \\
\hline $\begin{array}{l}\text { Left ventricle } \\
\text { diameter(mm) }\end{array}$ & $41.3 \pm 8.3$ & $42.3 \pm 6.6$ & 0.621 \\
\hline $\operatorname{LVEF}(\%)$ & $58.9 \pm 9.0$ & $57.2 \pm 7.8$ & 0.794 \\
\hline TAPSE $(\mathrm{cm})$ & $1.8 \pm 0.5$ & $1.9 \pm 0.4$ & 0.576 \\
\hline Blood glucose $(\mathrm{mg} / \mathrm{dL})$ & $116.5(40-540)$ & $119.5(30-328$ & 0.846 \\
\hline $\operatorname{Ureum}(\mathrm{mg} / \mathrm{dL})$ & $39.9 \pm 12.0$ & $38.0 \pm 15.3$ & 0.605 \\
\hline Creatinine $(\mathrm{mg} / \mathrm{dL})$ & $0.8 \pm 0.2$ & $0.9 \pm 0.1$ & 0.125 \\
\hline AST (IU/L) & $24.5 \pm 5.0$ & $25.7 \pm 4.2$ & 0.357 \\
\hline $\operatorname{ALT}(\mathrm{IU} / \mathrm{L})$ & $19.0 \pm 5.7$ & $17.8 \pm 6.3$ & 0.708 \\
\hline Haemoglobin (g/dL) & $13.1(12-15)$ & $13.6(12-16)$ & 0.370 \\
\hline Hematocrit (\%) & $40.1 \pm 3.7$ & $40.9 \pm 5.5$ & 0.505 \\
\hline Leucocyte $\left(10^{3} / \mu \mathrm{L}\right)$ & $10.5 \pm 3.5$ & $9.9 \pm 3.6$ & 0.524 \\
\hline Platelet $\left(10^{3} / \mu \mathrm{L}\right)$ & $207.2 \pm 70.6$ & $223.4 \pm 72.3$ & 0.391 \\
\hline Neutrophil (\%) & $75.7 \pm 11.3$ & $74.2 \pm 9.1$ & 0.585 \\
\hline Lymphocytes (\%) & $14.1 \pm 7.7$ & $16.3 \pm 7.7$ & 0.288 \\
\hline NLR & $6.2(1-32)$ & $5.1(1-26)$ & 0.286 \\
\hline RDW (\%) & $14.4 \pm 1.8$ & $13.3 \pm 1.5$ & 0.010 \\
\hline INR & $1.55(1.0-6.4)$ & $1.47(0.9-2.68)$ & 0.152 \\
\hline
\end{tabular}

To find out the independent predictor of LAT, multivariate logistic regression analysis was done for variables with a value of $\mathrm{p}<0.05$ (RDW level) and $\mathrm{p}<0.25$ (stroke, LA diameter, creatinine, and INR). Multivariate analysis showed that RDW was an independent predictor of LAT in patients with VAF (Table 2).

Table 2.

Independent predictors of LAT

\begin{tabular}{llll}
\hline Variables & OR & $P$ & $95 \%$ CI \\
\hline Stroke & 0.193 & 0.194 & $0.016-2.310$ \\
LA diameter & 1.107 & 0.175 & $0.956-1.281$ \\
Creatinine & 0.852 & 0.925 & $0.030-24.093$ \\
RDW & 1.619 & 0.020 & $1.079-2.429$ \\
INR & 2.426 & 0.129 & $0.773-7.614$ \\
\hline
\end{tabular}


Table 3.

Comparison baseline characteristic based on RDW cut-off value

\begin{tabular}{|c|c|c|c|}
\hline Variable & $\begin{array}{l}\text { RDW } \leq 13.5 \\
(\mathrm{n}=33)\end{array}$ & $\begin{array}{l}\text { RDW >13.5 } \\
(n=25)\end{array}$ & $P$ \\
\hline Age (year) & $46.6 \pm 13.9$ & $45.5 \pm 11.2$ & 0.745 \\
\hline Sex & & & 0.120 \\
\hline Male, n (\%) & $17(51.5)$ & $8(32)$ & \\
\hline Women, n(\%) & $16(48.5)$ & $17(68)$ & \\
\hline HT, n(\%) & $3(9.3)$ & 1(4) & 0.449 \\
\hline DM, n(\%) & $4(12.1)$ & $2(8)$ & 0.610 \\
\hline Stroke, n(\%) & $3(9.1)$ & $3(12)$ & 0.719 \\
\hline LA Thrombus, n(\%) & $10(35.7)$ & $18(64.3)$ & 0.002 \\
\hline LA Diameter(mm) & $50.1 \pm 4.2$ & $51.1 \pm 4.8$ & 0.423 \\
\hline $\operatorname{MVA}\left(\mathrm{cm}^{2}\right)$ & $0.6(0.4-0.9)$ & $0.7(0.4-1.0$ & 0.353 \\
\hline LV diameter (mm) & $40.4 \pm 6.7$ & $42.8 \pm 7.9$ & 0.232 \\
\hline LVEF(\%) & $59.4 \pm 8.2$ & $57.1 \pm 8.6$ & 0.308 \\
\hline TAPSE $(\mathrm{cm})$ & $1.9 \pm 0.4$ & $1.8 \pm 0.4$ & 0.476 \\
\hline Blood glucose (mg/dL) & $120(30-328$ & $\begin{array}{l}113(30- \\
540)\end{array}$ & 0.346 \\
\hline Ureum (mg/dL) & $36.5 \pm 15.6$ & $42.2 \pm 10.2$ & 0.103 \\
\hline Creatinine (mg/dL) & $0.9 \pm 0.2$ & $0.8 \pm 0.2$ & 0.608 \\
\hline AST (IU/L) & $25.6 \pm 4.1$ & $24.6 \pm 5.2$ & 0.431 \\
\hline ALT (IU/L) & $19.4 \pm 6.4$ & $17.1 \pm 5.5$ & 0.159 \\
\hline Hemoglobin (g/dL) & $13.7 \pm 1.5$ & $13.0 \pm 0.9$ & 0.038 \\
\hline Hematocrit (\%) & $41.7 \pm 4.9$ & $39.0 \pm 3.9$ & 0.028 \\
\hline Leucocyte $\left(10^{3} / \mu \mathrm{L}\right)$ & $10.6 \pm 3.4$ & $9.8 \pm 3.9$ & 0.357 \\
\hline Platelet $\left(10^{3} / \mu \mathrm{L}\right)$ & $216.9 \pm 65.5$ & $213.0 \pm 79.9$ & 0.879 \\
\hline Neutrophil (\%) & $75.8 \pm 10.4$ & $73.9 \pm 9.9$ & 0.504 \\
\hline Lymphocyte (\%) & $14.7 \pm 7.8$ & $16.1 \pm 7.8$ & 0.503 \\
\hline NLR & $\begin{array}{l}6.2(1.6- \\
26.2)\end{array}$ & $\begin{array}{l}\text { 4.6.(1.4- } \\
32.8)\end{array}$ & 0.371 \\
\hline INR & $1.4(0.9-4.3)$ & $1.6(1.1-6.4)$ & 0.065 \\
\hline
\end{tabular}

The RDW levels range from $11.2 \%$ to $18.7 \%$ (mean: $13.8 \pm 1.8 \%$ ) from total study population. Analysis of the ROC curve showed that RDW's optimum cut-off point in predicting LAT was $>13.5 \%$ with a sensitivity of $73.3 \%$ and specificity $64.3 \%$ (Figure 2). The area under the ROC curve for RDW in predicting the presence of LAT in VAF patients is 0.700 ; 95\% CI: $0.562-0.838$; $\mathrm{p}=0.009$ ).

Figure 2. ROC curve to determine RDW cut-off value for VAF patients with LAT. The cut-off value is $>13.5 \%$ with a sensitivity of $73.3 \%$ and specificity $64.3 \%$ (area under curve (AUC) 0,700; 95\% CI: 0.562-0.838; $\mathrm{p}=0.009$ ).

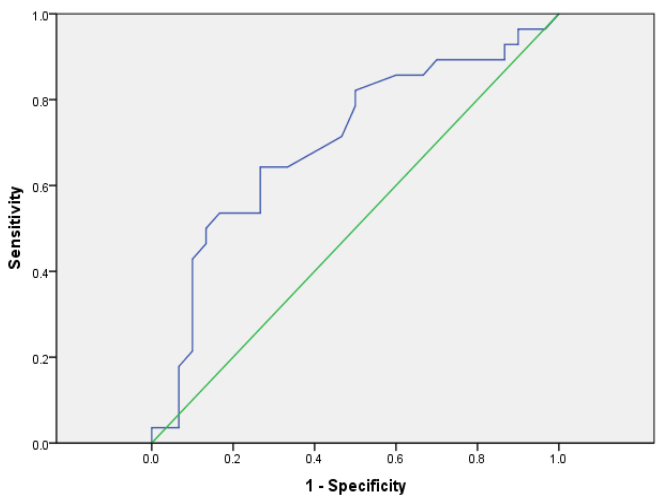

Figure 2. ROC curve to determine RDW cut-off value for VAF patients with LAT. The cut-off value is $>13.5 \%$ with a sensitivity of $73.3 \%$ and specificity $64.3 \%$ (area under curve (AUC)) 0,700 ; 95\% CI: 0.562-0.838; $\mathrm{p}=0.009$ ).

A comparison of patient characteristics based on RDW levels was presented in Table 3. There were $33(56.9 \%)$ patients have RDW levels $\leq 13.5 \%$ while 25 (43.1\%) patients had higher RDW $>13.5 \%$. Patients with RDW levels $\leq 13.5 \%$ and $>13.5 \%$ had similar inpatient demographic and comorbid characteristics. The prevalence of LAT was significantly higher in patients with RDW $>13.5 \%$ compared to those with RDW $<13.5 \%$ (64.3 $\%$ and $35.7 \%, \mathrm{p}=0.002$ ), with prevalence ratio is 5.91 .

\section{Discussion}

In this study, it was found that RDW was associated with LAT in VAF patients and was an independent risk factor for LAT formation. LAT was defined as homogeneous mobile or fixed mass with similar echo density to the myocardium located at the LA and LAA. ${ }^{2}$ RDW is a quantitative measure of the variability of circulating erythrocytes and mentioned earlier that can provide information about the prothrombotic status or poor complications of cardiovascular disease. ${ }^{4}$

In our study, the value of RDW was significantly higher in VAF patients with LAT than in VAF patients without LAT. RDW values $>13.5 \%$ can predict LAT with a sensitivity of $73.3 \%$ and specificity of $64.3 \%$. These results are by the research conducted by Belen et al., showing that RDW and platelet-lymphocyte ratio (PLR) are also independent risk factors for LAT formation. Although different results were obtained in bivariate analysis, where LA diameter and MVA were associated with LAT3, this different result was due to the study subjects whose patients with mitral stenosis were not all severe and occurred AF, whereas in our study the subjects taken were all patients with severe RMVS and AF.

The formation of thrombus in VAF patients due to RMVS is associated with a slowdown in blood flow and stasis in the LA due to valve obstruction, but this does not fully explain the mechanism of LAT formation in patients with RMVS and $20 \%$ incidence of emboli in these patients. In addition to stasis in the LA, inflammation, oxidative stress, platelet size, and RDW are also associated with thrombus formation in VAF patients. RMVS is an autoimmune 
inflammatory disease caused by infection Group A Streptococcus. The inflammatory reaction process can continue under subclinical conditions and result in valve damage. $^{2}$

A high RDW value is a marker of active inflammatory conditions and an increase in immature erythrocyte cells. Also, the presence of inflammation and oxidative stress are factors that perpetuate AF 5. Apart from the inflammatory process, several diseases such as immature erythrocytes (nutritional deficiencies such as iron, vitamin B12, and folic acid), increased erythrocyte destruction (such as hemolysis), impaired kidney function, and blood transfusions are conditions that can cause increased RDW. ${ }^{9}$

Increased inflammatory cytokines such as TNF- $\alpha$, IL-1b, and IL-6 in the blood can suppress the synthesis of erythropoietin (EPO) and hemoglobin which results in anemia. Inflammatory cytokines regulate erythropoiesis through two pathways. First, inflammatory cytokines inhibit the transcription of EPO genes in the kidneys and liver. Second, inflammatory cytokines inhibit erythroid cell mutations in the bone marrow. Erythropoiesis in the bone marrow is lowered by inflammatory cytokines, the process is mainly due to inhibition of erythroid progenitor cell proliferation and proerythroblast maturation. Regulation of inflammatory cytokines in bone marrow erythroid progenitor makes cells insensitive to EPO, this inhibits the function of anti-apoptosis and maturation. ${ }^{10}$ This increase in immature erythrocytes is reflected by an increase in RDW. ${ }^{11}$ Increased RDW indicates anisocytosis seen in peripheral blood smears and this indicates a heterogeneous size of erythrocyte population. This condition affects the maturation and function of erythrocytes. ${ }^{9}$ If erythrocytes function is impaired, it can increase the risk of erythrocytes adhering to endothelial cells and aggregation to form thrombus. ${ }^{9,10}$

Higher inflammation in the population of VAF with thrombus is also supported by the results of NLR, wherein the LAT group the NLR value was obtained $=6.1$ compared to the group without LAT with an NLR value of 5.1 although not significantly different. It is known that NLR is one of the inflammatory markers, and the study of Baysa et al. Shows that high NLR is associated with higher inflammation and the severity of RMVS. ${ }^{12}$

\section{Limitation}

This study only involved one agency with small sample size. The study was conducted retrospectively based on reports on echocardiographic results and patient medical records. Also, even though our anemia condition was excluded from the study, we did not examine the presence of iron deficiency, vitamin B12, and folic acid so that confounding factors still could not be eliminated. The echocardiographic modality used in this study is TTE, TTE has a low sensitivity in detecting thrombus in the LA and LAA compared to TEE. ${ }^{13}$ Further research is needed to find out the relationship of RDW to LAT formation in patients VAF with TEE modalities.

\section{Conclusion}

This study shows that a higher level of RDW has an association with the presence of LAT and an independent risk factor of LAT formation in patients with VAF. RDW is an easily obtained, low-cost and easily repeated parameter that seems effective for identifying VAF patients who are at high risk of developing LAT.

\section{Acknowledgement}

Authors thank to all of Dr. Moewardi General Hospital echocardiography laboratory staff for the assistance during study.

\section{References}

1. Nguyen TN, Hilmer SN, Cumming RG. 2013. Review of epidemiology and management of atrial fibrillation in developing countries. Int J Cardiol, 167:2412-2420.

2. Belen T, Ozal E, and Pusuroglu H. 2016. Relationship between the presence of left atrial thrombus in patients with mitral stenosis and platelet-tolymphocyte ratio. Anatol J Cardiol,16: 673-677.

3. Belen E, Ozal E, Pusuroglu H. 2015. Association of the CHA2DS2 VASc score with left atrial spontaneous echo contrast: a cross sectional study of patients with rheumatic mitral stenosis in sinus rhythm. Heart Vessels, 31:1537-1543.

4. Providencia R, Ferreira MJ, Goncalves L, Faustino A, Palva L, Fernandes A, et al. 2013. Mean corpuscular volume and red cell distribution width as predictors of left atrial stasis in patients with non-valvular atrial fibrillation. Am J Cardiovasc Dis, 3:91-102.

5. Zhao J, Liu T, Karantzopoulos P, Fu H, Shao Q, Suo Y, et al. 2015. Red blood cell distribution width and left atrial thrombus or spontaneous echo contrast in patients with non-valvular atrial fibrillation. Int J Cardiol,180:63-65.

6. Saric M, Lang RM, Krozon I. Quantification of Mitral Stenosis in Lang et al, ASE's Comphehensive Echocardiography 2th Edition. Philadelphia: Elsevier Saunders.2016, pp. 460-464.

7. Mancia G, Fagard R, Narkiewicz K, Rendon J, Zanchetti A, Bohm M, et.al. 2013. ESH/ ESC Guideline for the management of arterial hypertension. Eur Heart J, 34:2159-2219.

8. Ryden L, Grant P, Anker S, Berne C, Cosentino F, Danchin N, et.al. 2013. ESC Guidelines on diabetes, pre-diabetes, and cardiovascular diseases developed in collaboration with the EASD: the Task Force on diabetes, pre-diabetes, and cardiovascular diseases of the European Society of Cardiology (ESC) and developed in collaboration with the European Association for the Study of Diabetes (EASD). Eur Heart J, 34:3035-3087.

9. Gerede DM, Kaya CT, Vurgun VK, Acibuca A, Tak BT, Ongun A, et al. 2015 . Red cell distribution width as a 
predictor of left atrial spontaneous echo contrast in echocardiography. Medicine, 94:1-5.

10. Li N, Zhou H, Tang Q. 2017. Red blood cell distribution width: a novel predictive indicator for cardiovascular and cerebrovascular diseases. Dis Markers, 2017:7089493..

11. Eryd SA, Borne Y, Melander O, Persson M, Smith JG, Hedblad B, et al. 2014. Red blood cell distribution width is associated with incidence of atrial fibrillation. J Intern Med, 275:84-92..

12. Baysal E, Burak C, Cay S, Aksu T, Altintas B, Yaylak B, et al. 2015. The neutrophil to lymphocyte ratio is associated with severity of rheumatic mitral valve stenosis. Blood Med, 6:151-156.

13. Kim TS and Youn HJ. 2011. Role of echocardiography in atrial fibrillation. J Cardiovasc Ultrasound, 19:5161. 